\title{
The Hindu view on facts (Karman) as reflected in Bhagavad Gìtā and Upanishads and their role in Christianity
}

\author{
Fr. PhD. Alexandru-Corneliu ARION \\ Lecturer PhD, Faculty of Theology and Sciences of Education, \\ "Valahia" University of Târgovişte \\ ROMANIA \\ Email: alexcoarion@yahoo.co.uk
}

\begin{abstract}
Out of the four fundamental concepts or pillars of Indian religious thinking the present paper aims at disclosing the meaning and significance of the law of universal causality that binds man and cosmos, and condemns the former to an indefinite transmigration, i.e. the law of karma. This pan-Indian term will be underlined as it is reflected in the most important Upanishads and in Bhagavad Gìtā, the gospel of Hindu spirituality. On the final part a parallelbetween this concept and the teaching about the role of facts in the process of salvation according to the Orthodox Christian theology - will be drawn. In short, karma is a sort of law of causality that makes any action committed by individual leaving behind it a kind of force that causes the joys and sorrows of life, as the action was good or bad. According to Orthodox Church's teaching good deeds is, along with faith and grace the subjective conditions of salvation, i.e. personal appropriation by every man of the objective redemption brought about by Jesus Christ, the God-man. This appropriation called salvation or sanctification is not simply a gift from God, but a permanent action that lasts throughout human life. If the law of karma acts implacably and independently to the will of man, stamping a fatalist character to life and undermining the human freedom, in Orthodoxy, however, man is not alone, but permanently assisted by the divine grace. But grace does not work irresistibly; it respects human freedom, so the facts present an obvious synergetic character. Therefore, between the Christian teaching on facts and the philosophy of the act, as it emerges from the Upanishads and the Bhagavad Gìtā is an abysmal distance that comes to differentiate these two religions on this level as well.
\end{abstract}

Keywords: Karman, transmigration Bhagavad Gītā, Upanishads, acts, Brahman, ātman, Hinduism, Christianity, God, grace, salvation.

\section{INTRODUCTION}

There are four fundamental and supportive concepts, four main ideas that introduce us straight into the heart of Indian spirituality. These are: Karman, māyā, nirvana and yoga. One can write a coherent history of Indian thought starting from any of these fundamental concepts. Briefly, we can say that since post-Vedic era on, India has sought to understand particularly: 1) the law of universal causality that unites man with the cosmos, and condemns him to an indefinite transmigration: It's the law of Karman; 2) the mysterious process that generates and sustains the cosmos, thus enabling the "eternal return" of 
existences: this is māyā, the cosmic illusion; 3) the absolute Reality "located" beyond the cosmic illusion woven by māyā and beyond human experience conditioned by Karman; the pure Being (the Absolute), whatever the name, by which it is designated: Self, Brahman, the unconditioned, the transcendent, the indestructible, Nirvana etc.; 4) finally, the means to achieve Being, the suitable techniques to obtain the final release (moksha, mukti). [1]

Subsequently, we will look to analyse the first of four concepts i.e. that of Karman as reflected in the most important Upanishads and in Bhagavad Gītā, the synthesis of Hindu spirituality, trying then, a parallel between this concept and the teaching about the role of facts in the process of salvation according to the Orthodox Christian theology.

\section{Karma: origin, formulation and its importance in India's religions}

From the outset, we should mention that the two terms: Karman (deed) and transmigration (samsāra) of the first fundamental concept of Indian spirituality form a counterpart:

"Karma is a kind of law of causality that makes any action committed by individual leaving behind it a kind of force that causes the joys and sorrows of life, as the action was good or bad. Moreover, if these results (good or bad) cannot be achieved in the present life, the individual will incur inexorably into a future state, following current life, and whose terms will be determined by the totality of the individual's actions in the present life."[2]

In short, these are the coordinates that are part of the recurrent cycle of life.

In what manner it was to be found however, such a view? Here's a question that has tormented many philosophers, anthropologists, historians of religions, etc., especially from the Western, monotheistic sphere, alien of that concept. Today, the conviction of majority converges towards its correlation with another feature of Indian religions, namely that related to suffering. Perhaps more earnestly than did the Europeans, Hindu society members have put since immemorial time the pressing question of the origin of suffering and inequality of social conditions in which people live. Indian solution that comes to solve the great riddle of the origin of suffering and diversity of human conditions is to be found in the very word "karma" that through theosophists (19th century) has become familiar to Europeans ears.

Hindu believer considers, in a practical way, that one's well-being or suffering is merely the result of previous deeds (karma). This solution is not entirely satisfactory for it does not offer an answer about the inceptions. And yet - for Hindus - is a happy one, highly moral and at a large scale, a real one.[3]

Moving on to the haunting problem of suffering, it is to be noted that there is no suffering that is based on an undeserved judgment, resulting from social indifference. The entire suffering is fully deserved. Paradigmatic for illustrating this reality is the dialogue between German scholar Paul Deussen and an old pandit at Djaipur:

\footnotetext{
"To approach me he was looking for his path in a fumbling way. He said he was completely blind. Ignorant of born, I showed him my sympathy and I asked him what unfortunate accident caused the loss of his sight. The answer comes immediately on his lips and without any sign of bitterness he said: certainly for a crime committed in a previous life." The old man knew so good what the Laws of Manu learned people for so many centuries: Following a residue of guilt, which remains linked to previous crimes, are born idiots, blind, deaf and misshapen people, subjects of virtuous people's scorn. [4]
}

The doctrine of facts and their remuneration has been made in an early stage in precise terms: One reaps what one sows; no man inherits either good or bad act of anyone. 
The fruit is of the same quality with action, and good or evil, there is no possibility for any action to get destroyed."'[5]

Hindus, unlike the Greeks and Romans, notices the renowned Romanian indologist Theofil Simenschy not only limited themselves to declare the power of destiny opposing the will, and especially the deed. To the question: Why some are doing well, despite the fact they do not deserve it and although they are bad and others are unhappy, although they are good, intelligent and active?, insolvent for the Greeks and Romans, Hinduism respond through the teachings of Karman. This word also means "deed" and "destiny". It is the fact whose tracks are to be seen along the successive rebirths. The act relentlessly influences and changes destiny. This view is quite different from the Greek one, according to that destiny is fixed and nothing can change it.[6]

Despite the fact that the two concepts: Karman and transmigration (samsāra) are interrelated, in this study the focus will be on the former, as crystallized in the Upanishads and the Bhagavad Gītā.

\section{The Upanishads, the quintessence of Hindu wisdom}

The Upanishads are certainly among the fundamental texts of human thought. They are part of divine revelation (shruti) and are esoteric complements of "revealed" books of Vedas.

The word itself, upanishad was subject to several interpretations. Etymologically, it comes from the Sanskrit verb "sad" (to sit) preceded by the prefix "ni" - (below) and "upa" - (next to, beside), giving it the meaning as such: "Staying down beside [master]" - alluding to the specific attitude of learner in Veda. Hence the sense of "secret teaching", according to the esoteric nature of doctrine, or by extension "mystery".[7] However, not the "philosophical" aspect itself - in the European meaning of the word - is the distinctive character of these treaties, but their metaphysical and symbolic Oriental appearance. Upanishads, written at the dawn of philosophical speculation in India, retain a considerable amount of decadent era's mentality of the Vedas".[8]

Regarding the doctrine evolved by these mysterious texts one should mention that all ideas of Upanishads move around two basic concepts: Brahman and Ātman. The universe is Brahman. Ātman is but Brahman within us: "Verily, Brahman is the Self (Ātman) of us." (Brhadaranyaka 4, 4, 5).

The fundamental idea of the philosophy of the Upanishads can be expressed by the simple equation: Brahman $=\bar{A}$ tman.

\footnotetext{
"This identity of Brahman and Ātman, of God and the soul, is the keystone of the entire Upanishad's doctrine; in a concise fashion, it is expressed by "big words": tat tvam asi "Thou art that" (Chand. 6, 8, 7) and aham brahma asimi - "I am Brahman" (Brh. 1,4,10) . So, the authors of upanishadic ideas found the key to unraveling the mystery of nature in our own self when they recognized our Ātman, our innermost essence, as Brahman, the innermost essence of all nature and its phenomena".[9]
}

\section{The conception of deeds (Karman) in the text of the Upanishads}

Besides the ontological identity of Brahman and Ātman, another lesson of the Upanishads, regarding the eschatology, however, is that about facts and their position in the Hindu salvation sophisticated device (of salvation).

In the same period, in the writings of Brahmanas, the idea of retribution of human actions is taking shape increasingly stronger. Along with it appears the faith that after death 
a man can die again and not only once but several times. Besides, the phrase "repeated death" is used several times, but without indicating the precise content and the existential condition that occurs in the context. Despite that, this belief has been considered as a first suggestion of one of the fundamental teachings of Hindu Weltanschauung, namely the belief in transmigration.[10]

If Brahmanas texts had raised the sacrifice conception to the rank of ideology, exacerbating the role of priests, the Upanishads, as a reaction to the Brahmanic speculations about sacrifice, tried to prove its ineffectiveness. As the sacrifices hit the polytheistic beliefs, in the same way, in turn, they will be discredited and removed from practice and religious ideology through the new worldview and anthropology promoted by the Upanishads. Therefore, as when they believed in many gods, the sacrifice was raised to the rank of ideology, creating a distinct literature (Brahmanas), so it will happen with the sacrifices, assimilated and transfigured by the new religious spirit, manifested with the emergence of other literary texts: Upanishads.

According to Maitri Upanishad (I, 2, 9) those who projects illusions about the importance of sacrifice are deplorable because, after they had enjoyed heavens, the high place earned by good works, they will return to earth and will descend in a world below. Neither gods nor rites do really matter to a real sage (rshi). His ideal is admirably expressed in prayer forwarded by the oldest Upanishad: "From non-being (asat) lead me to being (sat), from darkness lead me to light, from death to immortality!'[11]

In the Upanishads the Vedic exterior sacrifice is therefore totally devalued: it is a "deed" (Karman) and any action, even of ritual nature, gives negative "fruits", for deeds bog down human being in metensomatosis cycles (samsāra).[12] The Upanishads speak, for the first time in Indian thought, about reincarnation (samsāra), which is tributary to the weight of our deeds (karman).[13]

What were the mechanism and logic that led to this fundamental concept for both Hinduism and other Indian religion (Buddhism, Jainism and Sikhism)? The answer consists, we could say, in a single word: desire. Man, always driven by a particular desire, act consequently, i.e. in order to achieve it.

The act, especially the ritual act (Karman) always lead to a result, and the link between act and "its fruit" is the warp of any individual life. So with all the facts, including those that must ensure paradise after death, and those that do not seem to lead to a concrete result in this life. Such action, particularly ritual act, condemns man (and the other living beings, too) to be reborn and die again endlessly.[14]

This doctrine was shared but only to a limited group of initiates:

\begin{abstract}
„Yâjñavalkya, 'he said', when the speech of this dead person enters into the fire, breath into the air, the eye into the sun, the mind into the moon, the hearing into space, into the earth the body, into the ether the self, into the shrubs the hairs of the body, into the trees the hairs of the head $[\ldots]$, where is then that person? 'Yâjñavalkya said': Take my hand, my friend. We two alone shall know of this; let this question of ours not be (discussed) in public. 'Then these two went out and argued, and what they said was Karman (work), what they praised was Karman, viz. that a man becomes good by good work, and bad by bad work. After that Ârtabhâga held his peace.' "[15]
\end{abstract}

Thus, on the backdrop of corresponding between man and cosmos, Yâjñavalkya formulates the theory of act as a determinant of the condition in a future existence, stressing the esoteric character of this theory. We come across here, presented in a lapidary form, the first witness of the theory of act in the Upanishads.[16]

This idea is developed and explained also by the same Yâjñavalkya: 
"That Self is indeed Brahman, consisting of knowledge, mind, life, sight, hearing [...], desire and no desire, anger and no anger, right or wrong, and all things. Now as a man is like this or like that, according as he acts and according as he behaves, so will he be [...] And here they say that a person consists of desires. And as is his desire, so is his will; and as is his will, so is his deed; and whatever deed he does, that he will reap."[17]

These passages, which form the starting point for all speculation on transmigration, suggest two fundamental ideas. Firstly, the individual fate is not put in connection with the divine, and secondly, it is determined by the very acts committed by the individual during his empirical lifetime. What determines the nature of existence after death is: thoughts, words and deeds of man who possess an ontological and moral consequence. This consequence, ontological and moral by nature, lies in the law of Karma (Sanskrit kri, = "to do").[18]

Because any act (Karman), religious or secular, amplify and perpetuate transmigration (samsāra), the release cannot be won either through sacrifice or by close ties with the gods, even through asceticism or charity. In their hermitages, rishis sought other means to liberate themselves.

An important discovery was made by meditating on the soteriological value of knowledge. Not knowing the sacrificial mystery was, after Brahmanas texts, what condemned people to a "second death". But rishis went further. They dissociated "esoteric knowledge" from its ritual and theological context; gnosis is considered able to capture the absolute truth, revealing deep structures of reality. Such "science" ends up by annihilating the very "ignorance" (avidya). It is, of course, an "ignorance" of metaphysical nature, because it refers to the ultimate reality, and not to empirical realities of everyday existence.[19]

In the Upanishads, human destiny has nothing to do with a divine agent of a personal nature (as were the Vedic gods), but with impersonal law of karma alone. Thus, from the perspective of Vedic polytheism, of a universe governed by a sovereign god (Varuna) through a law (rita) that was subordinated to him, it reached - in the Upanishads to a pantheistic perspective of the world, in which an impersonal law (karma) is governing. In this context, man is alone in front of his own destiny, marked only by the need to escape from the cycle consisting in sequences: avidya-karma-samsāra, a target that will form now on the foundation of all Indian philosophical-religious systems.[20]

The vicious circle avidya-karma-samsāra could be blocked only by knowing and annihilating his first cause, the desire:

\footnotetext{
"He who overcomes hunger and thirst, sorrow, passion, old age, and death. When Brâhmanas know that Self, and have risen above the desire for sons, wealth, and (new) worlds, they wander about as mendicants. For a desire for sons is desire for wealth, a desire for wealth is desire for worlds. Both these are indeed desires [...]; after he has done with that strength and learning, he becomes a Muni (a Yogi); and after he has done with what is not the knowledge of a Muni, and with what is the knowledge of a Muni, he is a Brâhmana".[21]
}

Thus, Upanishads bring a new vision of human deeds, by virtue of which every human action has an effect on its doer, forcing him to return in a new life experience, with a view to reaping the fruit of those facts. There should also be noted the aspect that samsāra disregards the moral value of acts committed, therefore, the good deeds inclusively throw human into a new reincarnation.[22]

The essential of act theory in the Upanishads consists, on the one hand, in giving up any activity (good or bad) because it engages man in the circuit of this world, which is 
nothing but illusion (maya), and on the other hand, the objective of supreme science (vidya), the only liberating, is Brahman:

Let a Brâhmana, after he has examined all these worlds which are gained by works, acquire freedom from all desires. Nothing that is eternal (not made) can be gained by what is not eternal (made). Let him, in order to understand this, take fuel in his hand and approach a Guru who is learned and dwells entirely in Brahman."[23]

At the time of Upanishads - and later - Indian thinking was troubled with the discovery of "the ways" (marga) to release from the infernal circle of transmigration, an effort crowned, over several centuries, by the famous synthesis of the Bhagavad Gitā.

\section{Bhagavad Gītā and the new philosophy of facts}

As a work drawn from the epic Mahābhārata, Gītā (as it is known in short) recorded the most widespread honour in India and outside India, being considered as a kind of "Gospel of Hinduism" (Louis Renou). If overall Mahābhārata is considered "tradition", Gītā is shruti (revelation), equal to the Vedas and Upanishads.

Bhagavad Gìtā is an important synthesis of Indian spirituality, because it attempts to assimilate systems like Vedanta, Samkhya and Yoga, along with the devotional Hinduism developed in Brahmanism. More than simply compiling them, Gìtā brings to the fore a new item, accessible to anyone, regardless of their social condition. [24]

As it was already noticed, for the Upanishadic thinking, the deed was considered the most serious obstacle to the release, this being yielded with the cessation of reincarnations through exhaustion of facts.

\footnotetext{
"The facts, virtuous or non-virtuous are merely projecting consciousness into the flow of rebirth (samsāra) and any condition - even the heavenly one - is obsolete; samsāra is temporality, and every existence is painful by its transitory nature. Indian spirituality (synthesized by Gitā) tried various solutions to exit the act determinism and the infinite cycle of samsāra."[25]
}

Compelled to lead a fratricidal struggle, the hero Arjuna is faced with the contradiction between individual morality - based on the doctrine of Karman - and obligations deriving from his commitment to life and society. The inner conflict of the hero springs out abruptly the moment he reached between the two armies, and seeing his relatives, Arjuna realized in a concrete way the horror that will take place. Overwhelmed by deep anguish that makes him to crash into his fighting chariot, he is about to abandon the fight. In this situation begins his great dialogue with divinity (Krishna), who presents him the state from the transcendental perspective.

He does exegesis of action in terms of moral and spiritual, theoretical and practical aspect, saying:

"A man does not attain freedom from action merely by not engaging in action; nor does he
attain perfection by mere renunciation. For nobody ever remains even for an instant
without performing some action"; No being can exist even for a moment without action.
Actions are based on modes (guna) of nature (prakrti) and can never be stopped."[26]

Sentenced to action, for "act is superior to non-acting" (Gìtā III, 8), man must fulfil the prescribed works, in other words, "the debts", facts that are incumbent by virtue to his particular situation.

"It is preferable to perform the duty according to one's own nature - even if the performance is imperfect - rather than perform the duties of others. The actions suitable for 
the nature of others should be feared. Death is preferable to preforming actions not compatible with one's nature." (III,35).

Krishna reveals to Arjuna that Being and Non-Being reside in Him and that all creation - from gods to minerals - descended from Him (VII, 4-6). He creates incessantly the world with the help of its Nature (prakrti), but that activity does not enfetter Him because $\mathrm{He}$ is but the spectator of his own creation:

"These acts do not bind Me, sitting as one neutral, unattached to them [...] By reason of My proximity, prakriti produces all this, the moving and the unmoving; the world wheels round and round, O son of Kunti, because of this.”[27]

It is precisely this valorisation, apparently paradoxical of activity that constitutes the capital doctrine revealed by Krishna: by imitation of God who creates and sustains the world without participating on it, man will learn to do likewise. And even if man refrains from action in the strict sense of the word, a whole unconscious set of activity, produced by the three gunas, continues to chain and to integrate him in karmic network. [28]

This imitation or even identification with God means, firstly, to imitate Him, as far as possible, and when you are a prince, like Arjuna, so defender by sword of dharma, the possibilities are greater. Krishna could, therefore, propose himself as role model.

\footnotetext{
"I have no duty, nothing that I have not gained, and nothing that I have to gain, in the three worlds; yet, I continue in action. If ever I did not continue in work, without relaxation, men would in every way, follow in My wake. If I did not do work, these worlds would perish.

$[\ldots]$ and I should ruin these beings".[29]
}

Here is, therefore, the proposed ideal of action: to act without a proper purpose, without the desire to get certain "benefit". Krishna is not limiting himself to stating that we cannot escape our svadharma[30], but it turns out to prove that fulfilling it, we accomplish the holiest act in terms of salvation, provided we do it without anger or hatred, without waiting for another's reward than divine friendship.

Thus, joining to Krishna in the battle for dharma, Arjuna becomes the "bringer of sacrifices" of this war, one that will ensure the victory of dharma and therefore will allow the continuance of the three worlds.[31]

Bhagavad Gītā strives to "save" all human works, to "give ground" to any profane action; for, by the very fact that he no longer enjoy the "fruits", man transforms his acts into sacrifices which help to maintain order cosmic. But Krishna recalled that only the acts committed as a sacrifice are not chaining:

"The world is bound by actions other than those performed for the sake of yajna; do thou therefore, O son of Kunti, perform action for yajna alone, devoid of attachment'. [32]

Every act, as such, must transmute into ritual (or sacrifice), as any effort to kill the desire, becomes, likewise, a war. So it is of no surprise if, in the Gītā we're witnessing a generalization of the use of the term yoga[33] - making it more than ever, impossible to translate. Arjuna's action must be an act of yoga, similarly to the act of the supreme deity. And because it is an action, his yoga is a karmayoga, or yoga of act. Practicing karmayoga eventually takes the seeker to the point of mental purification, oneness with humanity and inner peace by continually offering action selflessly to God and humanity. Ultimately Karma Yoga practise brings true knowledge of the Self and prepares one to be receptive to the divine light of God. The practicing of the selfless service in karmayoga is believed to lead with its purification of the mind and heart, to the turning of one's life into a spiritual act as a whole.[34] 


\begin{abstract}
"Karma Yoga, the great principle claims that the individual continue to perform his duties and ordinary activities of life, but with a new attitude of detachment from their fruits, that is to say from potential gains and losses which would entail. The world and the embodiment should not be abandoned, but the will of the individual must be united in act with the universal ground, and not with the vicissitudes of the suffering body. This is the teaching of the Creator incarnate. This is the world's balanced background of the supreme council he addressed to man". [35]

"The work of yajna, gift and austerity should not be relinquished, but it should indeed be performed; (for) yajna, gift and austerity are purifying to the wise. But even these works [...] should be performed, leaving attachment and the fruits; - such is My best and certain conviction".[36]
\end{abstract}

In this "ultimate opinion" of Krishna lies the key to transmutation profane activities into rites. Krishna reveals to Arjuna that "man of action" (i.e. one that cannot withdraw from civilian life to save through knowledge or asceticism or mystical devotion) can get to salvation, in other words, can escape the consequences of his participation to the world, however continuing to act. The only thing to be observed is as follows: he must get rid of his acts, in other words, "to give up the fruits of his deeds" (phalatrşna-vairagya), to act impersonally, without passion and desire, as if acting by proxy, in place of another. If he rigorously fulfills this rule, his actions will no more sow karmic potentialities, and, consequently, will not enslave him to karmic cycle[37]:

\begin{abstract}
"Forsaking the clinging to fruits of action, ever satisfied, depending on nothing, though engaged in action, he does not do anything. Without hope, the body and mind controlled and all possessions relinquished, he does not suffer any evil consequences [resulting from good and bad actions, for both lead to bondage], by doing mere bodily action.”[38]
\end{abstract}

So, one should not isolate himself from the world, but to live in it, nevertheless completely detached from the fruits of his actions; in other words, he can attain spiritual perfection by abandoning the generator of karma, which is pursuing of the fruit of the action. Krishna formulates herein the famous principle:

\footnotetext{
"Thy right is to work only; but never to the fruits thereof. Be thou not the producer of the fruits of (thy) actions; neither let thy attachment be towards inaction”; „Having made pain and pleasure, gain and loss, conquest and defeat, the same, engage thou then in battle. So shalt thou incur no sin.”[39]
}

The great originality of the Gītā is to insist on the "yoga of the deed" which is performed "renouncing the fruits of your acts" alone. This is the main cause of its success, unprecedented in India. For henceforth is allowed every man to hope for salvation, thanks to phalatrşna-vairagya, even when, for very different reasons, he will be forced to continue to participate in social life, have a family, occupy functions, even commit "immoral" acts, (like, e.g. Arjuna). Acting with detachment, without being driven by "the desire of the fruit" is to gain self-mastery and a serenity that only yoga can give. As Krishna says: "Although acts ceaselessly, he remains faithful to Yoga". This interpretation of Yoga technique, stresses out Mircea Eliade, is characteristic of the enormous effort of synthesis from Bhagavad Gìtā, who wants to reconcile all vocations: the ascetic, the mystical, or the one devoted to the activity in the world.[40]

Related to this new philosophy of facts, there must be underlined another idea of the poem, namely the devotion to God (bhakti). Complementarity between karma-yoga and bhakti-yoga lies in the double perspective that must be regarded by the follower of Gîtā's philosophy: the more disinterested must look to the fruits of his actions the better interested must be in devotion to Krishna, which should become the ultimate goal of his life. 
„Those who worship Me, resigning all actions in Me, regarding Me as the Supreme Goal, meditating on Me with single-minded Yoga, - to these whose mind is set on Me, verily, I become ere long [...]. If also thou art unable to practise Abhyâsa, be thou intent on doing actions - for My sake. Even by doing actions for My sake, thou shalt attain perfection."[41]

As an illustration of the central idea of the act philosophy of Gītā, we finally appeal to philosophical comparison, became a classic ever since the ancient Upanishads:

"He who does actions forsaking attachment, resigning them to Brahman, is not soiled by evil, like unto a lotus-leaf by water".[42]

So, like lotus leaves, which because of their smooth and oily surface are not affected by water they grow and abide in, similarly, the man settled in his Self: the waves of world he lives in do not destroy him.

\begin{abstract}
H. Zimmer writes down: „The technique of detachment taught by the Blessed Krishna through the Gîtā is a sort of "middle path." On the one hand his devotee is to avoid the extreme of clinging to the sphere of action and its fruits, while on the other hand the negative extreme of barren abstinence from every kind and phase of action is to he shunned with equal care".[43]
\end{abstract}

Because the universe is the creation of Krishna (the same with Vishnu), living in the world is not a "wrongdoing". "Wrongdoing" is to believe that the world, time and history have their own and independent reality, that there is nothing outside world and temporality. The idea is, in fact, pan-Indian one, but the most coherent expression of it was received in the Bhagavad Gītā[44].

\title{
teaching \\ V. Comparative view on acts role in Hinduism and according to Christian
}

According to Orthodox Church's doctrine good deeds is, along with faith and grace the subjective conditions of salvation, i.e. personal appropriation by every man of the objective redemption brought about by Jesus Christ, the God-man. This appropriation called salvation or sanctification is not simply a gift from God, but a permanent action that lasts throughout human life.

Unlike Christianity, religions from Eastern sphere (Hinduism and Buddhism) teach that the human being is comprised both of empirically determined and transient being, and of indefinite formless and eternal being, which represents the true self, and that man must take into account, preeminently in this life. Since the empirical world is illusory as ultimate value, the acts of man must contain a particular shade. Committing acts for the sake of the empirical world and of imprisoned life is to transform the relative and finite into absolute and infinite. Therefore, the facts and life of Eastern man bears the mark of detachment, attitude peculiar to his Weltanschauung. Man must work and live through detachment.[45]

Moving on to the philosophy of the Upanishads, there is a clear difference between this and the Christian teaching at the praxis level. Thus, in the Upanishads, the action either good or bad - engages man in samsāra circuit, wherein he returns even after a paradisiacal existence, after having exhausted the outgrowths of his acts. Therefore, he must give up any activity, seeking to free himself from the "fruits" of his acts. This release cannot be achieved except through withdrawal, isolation, meditating on the value of metaphysical knowledge (vidya). In the Upanishads, the highest goal is union with the Absolute, and this union can be acquired through intuitive knowledge only. In the 
Upanishads, as in later Indian philosophy, knowledge is the means par excellence for achieving liberation. [46]

According to Christian dogma, human activity in the body is not envisaged as evil or as punishment but a privilege, because through this activity, the man placed himself in direct contact with the levels of existence - also creatures of God - that he thereby understands, transforms and hence improves. By way of activity it is highlighted the mission of human as master of the nature, mission given to him by God at creation (Genesis 1, 28). And, freed from original sin by the sacrifice of Jesus Christ, man collaborates with the Creator to the transfiguration of living creature, as a priest of creation.[47]

In contrast with the impersonal agent of karma, whereby man can be propelled in a superior noetic and existential plane, Christian, through beneficial activities do not get something automatically and autonomously, for only God is able to appreciate out of the committed deeds our worthiness and as such give us the heavenly joy.

"Through good works man gives to God something finite, whereas God gives him the infinite, deification by grace.”[48]

Therefore, is impossible to talk about a qualitative equivalence between facts and their reward, as in the Upanishads.

If the law of karma acts implacably and independently to the will of man, stamping a fatalist character to life and undermining the human freedom, in Orthodoxy, however, man is not alone, but permanently assisted by the divine grace. But grace does not work irresistibly; it respects human freedom, so the facts present an obvious synergetic character.[49] Thus, the attitude toward facts should not be a negativistic one, avoiding them; on the contrary, St. Paul urges us to enrich this life with good works (I Tim. 6, 18) and "be not overcome of evil, but overcome evil with good." (Rom. 12, 21).

Regarding the ratio between and knowledge supreme love, Paul Deussen proposes a resolving of it - as a basis for ethics -, appealing to the famous Upanishadic formula: "tat tvam asi" ("That art Thou"). Of course, this view is not his own, but it enrols in the Âtman's metaphysical doctrine, which requires an ethical ideal. He affirms:

"The Gospels quite correctly establish as the highest law of morality 'Love your neighbour as yourselves'. But why should I do since by the order of nature I feel pain and pleasure only in myself, not in my neighbour? The answer is not in the Bible...but it is in the Veda, in the great formula That art Thou which gives in three words the combined sum of metaphysics and morals. You shall love your neighbour as yourselves because you are your neighbour".[50]

Starting from the famous Bhagavad Gītā's words: "He who knows himself in everything and everything in himself will not injure himself by himself, Indian philosopher Dr. Sarvepalli Radhakrishnan resolves this ethical ideal, writing:

"Every person round me is myself (me) at a different point of space and time and at a different grade of being. When one realizes that all beings are but the self, one acts not selfishly, but for all beings." [51]

We must state here concerning this "golden rule"- as important as in Christianity -, that you should treat others as yourselves is demonstrated in an unarguably logical manner, but only under the conditions we accept its premises. The principle of "loving one's neighbor as thyself" has validity in the Christian morality, not because the neighbor is myself or that both are but the Self (divine soul), but because we are all children of the same 
Heavenly Parent who imprinted in each of us a unique personal identity, unrepeatable and unrepeated.

Also in Christianity, knowledge, like virtue of love, does not lead to a fusion between the knowing subject and object of knowledge. The duality is maintained in the theognostic process, as in the soteriological one. God is transcendent in His being, therefore in Christianity "abyssus abyssum invocat" (Ps. 41, 9), i.e., according to the interpretation of St. Maximus the Confessor, the abyss of mind calls divine abyss. Starting from the transcendence of God, in Christian theognosia phenomenon, the mind remains distinct of Him. According to the theory of Yoga as illustrated in Gītā and Upanishads duality is destroyed, the whole forming an "eternal and unlimited divine 'ego'." In fact, this vision of the philosophy of the Upanishads starts from a pantheistic premise of the world, in which governs the impersonal law of karma, that man's final aim is the resorption or his existential annihilation, by identifying with the Absolute (Ātman or Brahman).[52]

In the Bhagavad Gittā we encounter a completely different conception concerning the function of deeds. Knowledge alone is by no means the only path that can lead to salvation. This can be achieved also through bhakti (devotional faith) or by activity. But activities in order to be effective with a view to redemption must be disinterested. Karmamärga (the path of deeds) has two phases. First, in which the adept must discharge all his religious and social debts in a complete indifference and detachment from their fruits. $\mathrm{He}$ offers a sacrifice to the Lord - of all his activities - such that they bind no more his soul to existence. Thus, detached from all desires, he achieved the final release.[53]

The next verse, eloquent for emphasizing the central message of the Gitan: „The world is bound by actions other than those performed for the sake of sacrifice; do thou therefore perform action for sacrifice (yajna) alone, devoid of attachment" (III, 9), has, so to speak, correspondence in the New Testament:

„Whether therefore you eat, or drink, or whatsoever you do, do all to the glory of God" (I Cor. 10, 31).

But the act of Gìtā loses any value because it has no moral weight. Moral categories of right and wrong are foreign to it, because the good and evil of any action do not depend on their external effects (on other individuals), but only on inner motivation by which it has been done. "The evil" of an action depends upon an undetached motivation that produces karmic debt, while "the good" holds on one completely detached, thanks to which it accumulates no such debt. This determination of the categories of good and evil is confirmed by Indian philosopher Surendranath Dasgupta, showing that:

"The characteristic feature of the Gìtā is its tendency to give non-moral content to all actions, by cutting all ties between action and its doer." [54]

But such an ideology lacks viability in the social plan. Therefore, to act in the world completely detached from the fruits of action is impracticable even in the Gita, where the hero Arjuna reaches apparently only to enter the battle completely detached, though in reality having changed only the motivation of his action.

\section{CONCLUSION}

First of all, in Christianity deed is first of all a morally good or bad act. In this sense, the act for a Christian has a soteriological and community, social value, because the collective good is the central concern of this religion. The saving dimension of deed is still lacking in the Bhagavad Gītā, because if the moral life can raise us up to a better existence, 
it cannot - by itself - to release the believer. An elevate spirit like Albert Schweitzer $(\dagger 1965)$, for example, is right when he argues that "moral behaviour is the only means for a better reincarnation, but does not produce release", and S. Radhakrishnan concludes that morality requires a separatist vision of life; when we transcend it, we rise above the moral laws.’[55]

Secondly, the act, in Christianity, has its origin not only in the human dimension but there are two realities intertwined in it: divine grace and human will. The reality of divine grace and the natural subject of man through his will meet each other, working actively for deeds generation and giving them a sanctifying value. The grace strengthens human nature and helps the will toward good. In this respect, good deeds are "fruits of the Holy Spirit" (Gal. 5, 22-24).

Thirdly, salvation is the reward of the facts we have done in life; separation of reward from act, as Gītā teaches, is unjustified. The act and the reward are actually, two aspects of a single reality. Judgment will reward the deed and deed's reward will be eternal life or eternal death, according to the good or bad nature of the deed. Good deed bears eternal life, and for that matter it neither present the effigy of indifference (lack of interest), nor it constitute the result of a debt (as in Gìtā), but it is a manifestation of faith and love for God and for humankind. In other words, "the being of good deed, in Christianity, is not indifference, apathy, but love of God and neighbour."[56]

Therefore, between the Christian teaching on facts and the philosophy of the act, as it emerges from the Upanishads and the Bhagavad Gîtā is an abysmal distance that comes to differentiate these two religions on this level as well. This is due to the fact that according to Orthodox theology, man, the "image of God", a microcosm - and a microtheos in becoming - has the sacred commitment to continue the divine work of perfecting of the cosmos, by an anabasis movement directed towards God, along with the entire creation. This purpose, so venturesome, is, however, fully achievable because the Christian God is not static or indifferent, but dynamic, active, both at "ad intra" level of the Holy Trinity, and at "ad extra" level, by His descent into the world, encountering the man on the thread of the uncreated energies; and the man can attain to himself only by complying with God, his model, Who is in perpetual motion and activity: "My Father is working until now, and I Myself am working" (John 5, 17).

\section{REFERENCES}

[1] Mircea Eliade, Yoga: Freedom and Immortality (Yoga-Nemurire şi libertate), trans. by Walter Fotescu, Humanitas, Bucharest, 1993, p. 95.

[2] Anton DumitriU, History of Logic (Istoria logicii), ed. III (revised and enlarged), vol. I, Tehnică Publishing House, Bucharest, 1993, pp. 64-65.

[3] L. de la Valle Poussin, "Karma", in: Encyclopaedia of Religion and Ethics, edited by James Hastings, vol. VII: Hymns-Liberty, T\&T Clark, Charles Schribner's Sons, London; New York, 1955, p, 673.

[4] J. T. ADDISON, Viaţa după moarte în credinţele omenirii (The afterlife in the beliefs of mankind), transl. by Victoria Comnea şi Dan Dumbrăveanu, Herald Publishing, Bucharest, 1996, pp. 104-105 passim.

[5] L. de la Valle Poussin, art. cit., p, 674.

[6] Theofil. SimensCHY, Cultură şi filosofie indiană în texte şi studii (Indian culture and philosophy in texts and studies), cared for edition, Foreword and notes by Cicerone Poghirc, Ştiinţifică şi Enciclopedică Publishing, Bucharest, 1978, pp. 99, 146 passim.

[7] ***, Cele mai vechi Upanişade (The Oldest Upanishads), transl., foreword, notes and comments by Radu BERCEA, Ştiinţifică Publishing, Bucuharest, 1993 p. 17.

[8] Mircea Eliade, Erotica mistică în Bengal. Studii de indianistică (Mystical Erotica in Bengal. Indian Studies), Jurnalul literar Publishing, Bucharest, 1994, p. 62. 
[9] Paul Deussen, Filozofia Upanişadelor (The philosophy of the Upanishads), transl. by Cornel Sterian, Tehnică Publishing, Bucharest, 1994, pp. 40-41 passim.

[10]Dr. Remus Rus, "Concepţia despre om în marile religii" ("The conception of man in the great religions"), in: Glasul Bisericii (Voice of the Church), year XXXVII, no. 7-8, 1978, p. 817.

[11] Brhadaranyaka Upanişad, I, 3, 28; Mircea ELIADE, Istoria credinţelor şi ideilor religioase (History of beliefs and religious ideas - H.B. \& R.I.), vol. I, transl. by Cezar Baltag, Ştiinţifică şi Enciclopedică Publishing, Bucharest, 1981, p. 251.

[12] Mircea Eliade şi I. P. Culıanu, Dicţionar al religiilor (Dictionary of Religions), transl. by Cezar Baltag, Humanitas Publishing, Bucharest, 1993, p. 171.

[13]Fernand COMTE, Cărţile sfinte (The Sacred Books),transl. by Dumitru Purnichescu, Enciclopedică Publishing, Bucharest, 1994, p. 98.

[14] Madeleine BIARDEAU, Hinduismul, antropologia unei civilizatiii (Hinduism, Anthropology of a civilization), transl. by Ileana Busuioc, Symposion Publishing, Bucharest, 1996, pp. 36-37.

[15] Brh.-Up. III, 2, 13-14, p. 61.

[16] Radu BERCEA, op.cit., p. 131 (in notes to Brh.-Up.).

[17] Brh.-Up. IV, 4, 5, p. 84.

[18]Dr. Remus RUS, op. cit., p. 818

[19] Mircea EliaDE, H.B. \& R.I., vol. I, p. 252, passim. In this sense, of "metaphysical ignorance" the term avidya was imposed in Indian philosophical vocabulary

[20] Ernest VAlEA, Creştinismul şi spiritualitatea indiană (Christianity and Indian spirituality), Ariel Publishing, Timişoara, 1996, p. 27.

[21] Brh.-Up., III, 5.1.

[22] Ernest VALEA, op.cit., pp. 25-26. In this regard, the words of Mundaka-Upanishad are exemplary: "Because those who depend on their good works are, owing to their passions, improvident, they fall and become miserable when their life (in the world which they had gained by their good works) is finished. Considering sacrifice and good works as the best, these fools know no higher good, and having enjoyed (their reward) on the height of heaven, gained by good works, they enter again this world or a lower one." (I, 2, 9-10). Cf. http://www.sacred-texts.com/hin/sbe15/sbe15017.htm

[23] Mundaka-Upanişad I, 2, 12; apud Theofil SIMENSCHY, op.cit., p. 139.

[24] Ernest VALEA, op.cit., p. 114.

[25] ***, Bhagavad Gītā, translated from Sanskrit, commentary and explanatory notes by Sergiu AL-GEORGE, Societatea Informaţia Publishing, Bucharest, 1994, p. 18.

[26] Bhagavad Gītä, III, 4-5.

[27] Srimad-Bhagavad-Gìtā, IX, 8-10, English translation and commentary by Swami Swarupananda, [1909], at: http://www.sacred-texts.com/hin/sbg/sbg14.htm

[28] Mircea ELIADE, H.B. \& R.I., vol. II, p. 234.

[29] Srimad-Bhagavad-Gītā, III, 22-24.

[30] From Sanskrit sva, 'own', + dharma, 'duty, right', i.e. one's own right, duty, or nature; one's own role in the social and cosmic order. Svadharma is relative to one's caste and stage of life (cf. varnāáśramadharma), and to one's situation (cf. āpaddharma). Svadharma or relative dharma often conflicts with sādhāraṇa dharma, universal dharma, or sanātana dharma, absolute or eternal dharma. For example, to kill is a violation of eternal dharma, yet a warrior's svadharma (own duty, nature) is to kill. V. "Svadharma", in: The Concise Oxford Dictionary of World Religions, 1997, originally published by Oxford University Press 1997.

At: $\quad$ http://www.encyclopedia.com/religion/dictionaries-thesauruses-pictures-and-pressreleases/svadharma

[31] Madeleine BIARDEAU, op.cit., pp. 155-157 passim.

[32] Bhagavad Gìtā, III, 9. Yajna means a religious rite, sacrifice, worship, or an action done with a good or spiritual motive. It also means the Deity. The Taittiriya-Samhitâ (I.7.4.) says, "Yajna is Vishnu Himself." See supra note 30 .

[33] In Vedic Sanskrit, yoga (from the root yuj) means "to add", "to join", "to unite", or "to attach" in its most common literal sense. By figurative extension from the yoking or harnessing of oxen or horses, the word took on broader meanings such as "employment, use, application, performance" (compare the figurative uses of "to harness" as in "to put something to some use"). All further developments of the sense of this word are post-Vedic. More prosaic moods such as "exertion", "endeavour", "zeal", and "diligence" are also found in Indian epic poetry. V. Monier MoniER-WILliams, A Sanskrit-English Dictionary: ...with 
Special Reference to Greek, Latin, Gothic, German, Anglo-Saxon, and other cognate Indo-European languages, Oxford Clarendon Press, 1872, p. 804.

[34] In this practice, one is seen as being used as an instrument in the hands of God without expectation of reward in return but rather an act of worship. See Linda WOODHEAD, Christopher H PARTRIDGE, and Kiroko KAWANAMI, Religions in the modern world, London and New York: Routledge, 2009, p. 378.

[35] Summarizes the renowned indologist Heinrich ZIMMER. In: Filosofille Indiei (Philosophies of India), transl. by Sorin Mărculescu, Humanitas Publishing, Bucharest, 1997, p. 261.

[36] Bhagavad Gìtā, XVIII, 5-6, p. 366.

[37] Mircea EliADE, H.B. \& R.I.., vol. II, p. 235.

[38] Bhagavad Gìtā, IV, 20-21, pp. 107-108.

[39] Ibid, II, 47, 38, p. 57, 51. Be thou not the producer, etc.: That is, do not work with any desire for results, for actions produce fruits or bondage only if they are performed with desire.

[40] Mircea Eliade, H.B. \& R.I.., vol. II, pp. 235-236. See also idem: Yoga, nemurire şi libertate (Yoga, Immortality and Freedom), transl. by Walter Fotescu, Humanitas Publishing, Bucharest, 1993, p. 142.

[41] Bhagavad Gittā, XII, 6-7, 10. Abhyâsa-Yoga: the practice of repeatedly withdrawing the mind from the objects to which it wanders, and trying to fix it on one thing.

[42] Ibid, V, 10, p. 125.

[43] Heinrich ZIMMER, Philosophies of India, edited by Joseph Campbell, Routledge \& Kegan Paul LTD Broadway House: Carter Lane, London, 1953, pp. 403-404.

[44] Mircea Eliade, H.B. \& R.I.., vol. II, p. 207.

[45] Dr. Remus RUS, op.cit., p. 856.

[46] Hajime NAKAMURA, Orient şi Occident: $O$ istorie comparată a ideilor (East and West. A Comparative History of Ideas), transl. by Dinu Luca, Humanitas Publishing, Bucharest, 1997, p. 140.

[47] Magistr. Emil ROMAN, „Învăţătura despre karma în cugetarea religioasă indiană şi rolul faptei în mântuirea subiectivă după învăţătura ortodoxă" ("The doctrine of karma in Indian religious thinking and the role of fact in subjective redemption process according to the Orthodox teaching"), in: Orthodoxy, XVII (1965), nr. 4, Bucharest, pp. 558-559.

[48] Pr. prof. Dumitru STĂNILOAE, „Faptele bune în învăţătura ortodoxă şi catolică” (“The good deeds in the Orthodox and Catholic teaching"), in: Orthodoxy, VI (1954), nr. 4, p. 533.

[49] For Eastern spirituality, human acts are in no way moral actions, but theandric energy, human work inside the divine work. It is paradigmatic in this respect, the formula of St. Maximus the Confessor: "Man has two wings in order to get to heaven: freedom, and along with it, the grace". Apud Paul EVDOKIMOV, Ortodoxia (The Othodoxy), transl. by dr. Irineu Ioan Popa, IBMBOR Publishing, 1996, p. 112.

[50] Apud Sarvepalli RADHAKRISHNAN, Estern Religions and Western Thought, 2-nd edition, London, 1955 , pp. 101-102.

[51] Ibid, p. 102.

[52] For details: Dr. Corneliu-Alexandru ARION, Panteismul hinduist şi învăţătura creştină despre Dumnezeu (Hindu pantheism and the Christian teaching on God), Enciclopedică Publishing House, Bucharest, 2010, pp. 323-

[53] R. L. TURNER, "Karma-mārga", art. in: Encyclopaedia of Religion and Ethics, ed. by James HASTINGS, vol. VII: Hymns-Liberty, T\&T Clark, Charles Schribner's Sons, London; New York, 1955, p. 678.

[54] Surendranath DAsGUPTA, The History of Indian Philosophy, Motilal Banarsidass, vol. II, 1991, p. 507.

[55] Sarvepalli RADHAKRISHNAN, op.cit., pp. 103-104.

[56] Hristu Andrutsos, Dogmatica Bisericii Ortodoxe Răsăritene (Dogmatic of Eastern Orthodox Church), transl. by Rev. Dumitru Staniloae, Tipografia Arhidiecezan Publishing, Sibiu, 1930, p. 260. 